\title{
Celebrity Endorsement, Brand Equity, and Consumer Purchasing Decisions
}

\author{
A Almaida ${ }^{1}$, I F Nurqamar ${ }^{2}$, R Setiawan ${ }^{3}$ and Yulianingsi ${ }^{4}$ \\ \{astyalmaida@unhas.ac.id ${ }^{1}$ \} \\ 1,2,3,4 Management Department, Universitas Hasanuddin, Indonesia
}

\begin{abstract}
This study aims to examine the role of celebrity endorsement and brand equity in purchasing decision. The data used in this research was obtained from questionnaires. The research model was tested quantitatively through a field survey of 150 Hasanuddin university students using multiple linear regression analysis with SPSS (Statistical Product and Service Solutions). The results of this study indicate that celebrity endorsement and brand equity have positive and significant effect on the purchasing decisions. Brand Equity is the most influential variable to the purchasing decision. Given the importance of consumer purchasing decisions for business sustainability and often contributing strategically, this research has implications for theoretical and practical development.
\end{abstract}

Keywords: Celebrity Endorsement, Brand Equity, Purchase Decision

\section{Introduction}

When facing intense competition, having only a good is no guarantee of being among the top-notchers of the market. Many -even most- most businesses rely on celebrity endorsement to advertise their product. Celebrities have been involved in endorsing various activities since the eighteenth century (Roy, 2006; Khan et al. 2016) and are even more successful today (Gauns et al. 2017).

Celebrities are claimed as the most influential icons that people admire and easily attracted to. Companies spend a huge amounts to get endorsement (Abdussalam \& Johnson, 2017), believing that celebrities can acts as the brands' spokespeople. They -the celebritiescertify each brand's claim and confirm each brand's position by attributing to the brand their own personality, popularity, and status in the society or expertise in the field to the brand (Sivanandamooorthy, 2013; Murugananthan, 2009; Shimp , 2003). To see them using the products, demanding the services and enjoying the experiences stimulates consumers to buy (Shazzana, 2015).

Endorsers are people, famous or not, who deliver advertising messages and encourage others to buy a product (Royan, 2004). Celebrities are influential because people admire them and find them attractive. (Spry, 2011) says that celebrity endorsers are the most effective promotional tool and affect the effectiveness of advertising, product recognition, brand recall, desire to buy and even buying decisions themselves. Through celebrity endorsement, marketers, at the same time, can distance their ware from competitors' products in the same market. This differentiation is very important when consumers choose from a variety of similar products, services, or experiences.

Another way to differentiate is through brand equity, the strength of a brand. According to Kotler and Keller (2009), brand equity is the added value bestowed by the brand. Brand equity can be reflected in the way consumers think, feel and act in relation to the brand, and it can be measure in dollars by the price, market share, and profitability that the brand provides 
for the company. Through strong brands, companies can manage their assets well, increase cash flow, expand market share, set premium prices, reduce promotional costs, increase sales, maintain stability, and increase competitive advantage. From consumer perspective, brand equity is the benefit from loyalty to a brand.

From the ancient times, appearance is one of the crucial things that matter for women. Some of them believe that confidence stems from being a beauty. Consequently, some woman show concern about the types of the cosmetics that they want to use to look prettier.

To study this concern, this study focus on the beauty products Bedda' Lotong, Mabello. s natural skin-lightening body scrub from the Bugis people of South Sulawesi, in the southwestern province of the third largest of Indonesia's 17.000 islands.

Research on local product driving economic advancement based on the endorsement is still rare in Indonesia. Previous studies look at brand equity and purchasing decision. This study analyzes the effect of celebrity endorsement and brand equity on the purchasing decisions of Hasanuddin university, Makassar, Indonesia.

\section{Literature Review}

\subsection{Celebrity Endorsement}

According to Shimp (2003), celebrity endorsement is the use of a public figure who is widely known by many people for their success in their respective fields as an artist, entertainer, athlete, and so on to have a positive influence on marketing due to their achievements and public image. Royan (2004) lists attractiveness, trustworthiness, and expertise among desirable characteristics.

Attractiveness refers to intelligence, personality traits, lifestyle, physical attractiveness, and personal attractiveness of the endorser. Trustworthiness refers to honesty, fairness, and credibility of an endorser (Endorgen et al. 2001). Expertise refers to the knowledge, experience, or skills possessed by an endorser associated with the advertisement.

People are often fixated upon and obsessed by celebrities and at times secretly feel illogical familiarity with them because they reinforce the fan's self-image or desired identity (Nayar, 2009). Celebrity endorsement can reify a consumer's recall of a brand and consume assessment of the products (Clark \& Hortsman, 2003)

Celebrities reinforce attitudes and emotions, let alone sales (Kanungo \& Pang, 1973; Bowman 2002). Celebrity endorsements rely on the effective segmentation, targeting and positioning (STP) of their products in any specified market; hence demographic profiling of the consumer is crucial, lest the STP become ineffective (Gauns et al. 2017).

\subsection{Brand Equity}

As above, Kotler \& Keller (2009) measure brand equity by a brand to product, service and experiences. Brand equity reflects the way consumers think, feel, act and also affects the price, market share and profitability. Brand equity is the totality of brand perception, covering the relative quality of products and services, financial performance, customer loyalty, satisfaction and overall brand appreciation (Knapp D. E., 2001). If a consumer is not interested in a brand and buys because of product characteristics, price, and comfort, the possibility of brand equity is low. On the other hand, if the customer tends to buy a brand despite other superior products possibly superior in quality, offering similar terms of price and feature, then the brand has an equity value. 
Brand equity encompasses several elements like brand loyalty, brand awareness, perceived quality, brand association, and other proprietary brand assets that have marketing value (Pride $\&$ Ferrel, 2009). Brand loyalty refers to whether or not a customer might switch to another brand, especially if the branded product changes in price or in other ways (Rangkuti, 2002). Aaker (1997) defines brand awareness as the ability of a prospective buyer to recognize or recall that a brand is part of a particular product category. Perceived quality refers to the customer's overall response to the quality and excellence that the brand offers. Brand association refers to all impressions that arise in consumers' minds related to their memory of a brand (Durianto, 2004).

\subsection{Purchase Decision}

According to (Fishbein \& Ajzen, 1975), purchasing intention is 'a subjective inclination' by customers towards a certain product or service and it can be the critical factor for predicting consumers' behaviour. Despite many product choices offered by companies to fulfil people's wants, the purchase intention of costumer controls their decision whether or not to buy any particular product, if the buy at all.

(Kotler \& Armstrong, 2008) defines consumer purchasing decisions more simply as buying the most preferred brand from various alternatives, but two things can intervene between intention and decision. The first factor is the attitude of others. The second factor is situational factors. Therefore, purchase preferences and intentions do not always produce actual purchases. There are five stages of purchasing decision: problem recognition, information retrieval, alternative evaluation, purchasing decisions and afterwards, and postpurchase behavior (Kotler \& Keller, 2009). Obviously, the decision process begins long before the actual purchase and has consequences for a long time afterward.

\subsection{Celebrity Endorsement, Brand Equity, and Consumer Buying Decision}

Celebrity endorsement is ubiquitous in modern marketing (Kurzman et al. 2007). Research proves that celebrity endorsement has a positive effect on consumer purchase intentions, and the advertising industry has been using it for years (Kenyon et al. 2012). A survey in India indicates that sales remain high even if the celebrity is involved in a scandal (Chaturvedi, 2014).

Other studies in India find that, in general, there are seven celebrity attributes responsible for the change in purchase intention; two (trustworthiness and expertise) affecting credibility, three (similarity, familiarity, likeability) affecting attractiveness, product match-up with the celebrity and meaning transfer from celebrity towards the product (Gauns et al. 2017).

According to a study conducted by Elberse \& Verleun (2012), celebrity support increases product sales by an average of $4 \%$ during the endorsement period. They also show that media publicity gained by celebrities (for example, by winning tournaments) can further increase sales (Elberse \& Verleun, 2012). Martey \& Frempong (2014) and (Keel, 2012) confirms this.

Brands are important intangible assets and a source of competitive advantage for company. Brand Equity is brand value, that is invaluable to producers and consumers, reflects the total value from outside, quality, difference, perfect personality, acceptable prices and a very standard distribution network and customer loyalty. Brand Equity helps simplify consumer choice, help create trust. Effective branding allows consumers to easily identify the desired company or product because their features and benefits have been effectively communicated. Positive and established brand associations increase the likelihood that consumers will choose, buy, and consume products. 
Some studies have succeeded in proving a positive relationship between brand equity and purchasing decisions (Akhtar et al. 2016; Fouladivanda et al. 2013). Yoo et al. (2000), state that the first four variables from Aaker (1991) (i.e. brand awareness, brand association, perceived quality and brand loyalty) are important factors that influence the purchasing decision process from a consumer perspective.

\section{Methodology}

\subsection{Research Design}

Data are collected through a questionnaire, using a nonprobability technique. The Mabello body scrub, a local product, most strongly links to the 18-25 age group, so we define our target population as students of the Economic and Business Faculty, Universitas Hasanuddin, that use Mabello Product in the last 3 (three) months.. Yoo et al. (2000) confirm the use of student respondents especially when they are the main consumers of the selected product. Using a nonprobability sampling technique, 150 respondents are selected as a sample.

\subsection{Questionnaire and Measurement Method}

The questionnaire was prepared with five-point Likert. All questions to measure each construct are adapted from previous research. Nine question indicators for measuring celebrity endorse variables were adapted from Ohanian (1990). Twelve question indicators for measuring brand equity were measured through a scale adapted from Yoo et al (2000) while fifteen question indicators for measuring consumer purchasing decisions were adapted from McKnight \& Chervany (2002); Wang \& Chang (2013) and Yoo \& Donthu (2001). All indicators of questions using a five-point Likert scale ranging from $1=$ Strongly Disagree to 5 $=$ Strongly Agree. Validity and Reliability Test.

In order to measure the validity, the significance score of each item is measured by coefficient correlations. Significance greater than 0.05 is acceptable. Reliability measures the consistency and stability of the instruments used in the survey when repeated measurements are made. A value of Cronbach alpha greater than 0.6 is acceptable and good.

\subsection{Data analysis}

The switching propensity model tests the relationship between each individual component of celebrity endorsement, brand equity, and purchasing decision.

$$
Y=a+b_{1} X_{1}+b_{2} X_{2}+6
$$

Where,

Y : Purchasing Decision

a : Constant Factor

$\mathrm{b}_{1} \mathrm{X}_{1}$ : Celebrity Endorser

$\mathrm{b}_{2} \mathrm{X}_{2} \quad$ : Brand Equity

e : Error Term 


\subsection{Conceptualization and Hypothesis Development}

Figure 1 below shows the relationship between variables. Celebrity endorser and brand equity are considered as dependent variables whereas purchasing decision is the independent variable.

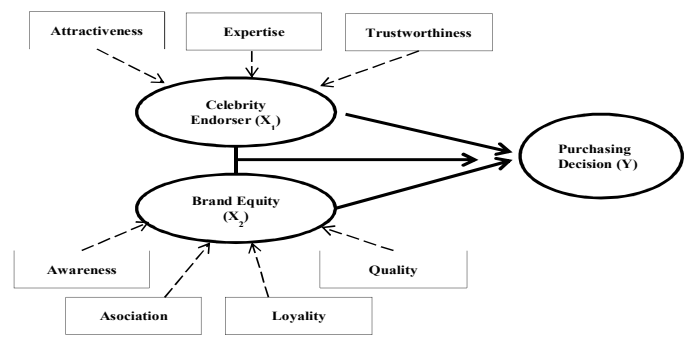

Fig. 1. Conceptual Framework

\section{Results And Discussion}

\subsection{Validity and Reliability}

All the indicators of variables are stated as valid. The validity test shows that the probability of correlation is less than $0.05(5 \%)$ and the research instrument as stated is valid. For $\mathrm{X}_{1}$, the Alpha Cronbach is 0.922 ; for $\mathrm{X}_{2}$, the Alpha Cronbach is 0.894 ; and for $\mathrm{X}_{3}$, the Alpha Cronbach is 0.929. The Alpha Cronbach of the entire variable is higher than 0.6, therefore the research instrument is reliable.

\subsection{Multiple Regression Test}

Table 1. Multiple Regression Test

\begin{tabular}{|c|c|c|c|c|c|c|}
\hline \multicolumn{7}{|c|}{ Coefficients $^{\mathrm{a}}$} \\
\hline \multirow{2}{*}{\multicolumn{2}{|c|}{ Model }} & \multicolumn{2}{|c|}{$\begin{array}{l}\text { Unstandardized } \\
\text { Coefficients }\end{array}$} & \multirow[b]{2}{*}{$\begin{array}{r}\text { Bet } \\
\mathrm{a}\end{array}$} & \multirow[t]{2}{*}{$\mathrm{t}$} & Sig. \\
\hline & & B & Std. Error & & & \\
\hline \multirow[t]{3}{*}{1} & $\begin{array}{l}\text { (Const } \\
\text { ant) }\end{array}$ & $\begin{array}{r}6.84 \\
5\end{array}$ & 3.251 & & $\begin{array}{r}2.10 \\
6\end{array}$ & .037 \\
\hline & $\begin{array}{l}\text { Celebri } \\
\text { ty } \\
\text { Endors } \\
\text { er }\end{array}$ & .451 & .108 & $\begin{array}{r}.28 \\
7\end{array}$ & $\begin{array}{r}4.17 \\
5\end{array}$ & .000 \\
\hline & $\begin{array}{l}\text { Brand } \\
\text { Equity }\end{array}$ & .765 & .091 & $\begin{array}{r}.58 \\
0 \\
\end{array}$ & $\begin{array}{r}8.43 \\
8 \\
\end{array}$ & .000 \\
\hline a. & Depende & Varia & TOTALLY & & & \\
\hline
\end{tabular}

The equation is as follows:

$$
Y=6.847+0.451 X_{1}+0.765 X_{2}
$$

1. The constant value (a) or intercept is 6.847. It shows the influence of Celebrity Endorser $\left(\mathrm{X}_{1}\right)$ and Brand Equity $\left(\mathrm{X}_{2}\right)$ on Consumer Purchasing Decision (Y). If all independent variables are zero then Purchasing Decision will be predicted to be as much as 6.847 . 
2. If the others are constant, an increase of Celebrity Endorser $\left(\mathrm{X}_{1}\right)$ will result in an increase of Purchasing Decision (Y).

3. If the others are constant, an increase of Brand Equity $\left(\mathrm{X}_{2}\right)$ will result in an increase of Purchasing Decision (Y).

\subsection{Hypothesis Testing}

Table 2. F-Test Result

\begin{tabular}{|c|c|c|c|c|c|c|}
\hline \multicolumn{7}{|c|}{ ANOVA $^{b}$} \\
\hline & odel & $\begin{array}{l}\text { Sum of } \\
\text { Squares }\end{array}$ & $\mathrm{df}$ & $\begin{array}{c}\text { Mean } \\
\text { Square }\end{array}$ & $\mathrm{F}$ & Sig \\
\hline 1 & $\begin{array}{l}\text { Regress } \\
\text { ion }\end{array}$ & 4899.766 & 2 & 2449.883 & $\begin{array}{r}139 . \\
071\end{array}$ & $\begin{array}{r}.00 \\
0^{\mathrm{a}} \\
\end{array}$ \\
\hline & $\begin{array}{l}\text { Residua } \\
1\end{array}$ & 2589.568 & 147 & 17.616 & & \\
\hline & Total & 7489.333 & 149 & & & \\
\hline
\end{tabular}

a. Predictors: (Constant), Celebrity Endorser, Brand Equity

b. Dependent Variable: Purchasing Decision

Source: Data Processed, 2018

As shown, the $\mathrm{F}$ value is 139.071 with the level of sig.0.000. The degree of freedom 1 (numerator) is 2 and degree of freedom (denumerator) is 147 , then $\mathrm{F}_{\text {table }}$ is $3.06 . \mathrm{H}_{1}$ can be accepted if the number of $\mathrm{F}_{\text {count }}>\mathrm{F}_{\text {table }}=139.071>3.06$, or the sig. $\mathrm{p}<0.05$. Therefore, in this case, $\mathrm{H}_{1}$ is accepted, means that independent variables simultaneously influence the dependent variable.

Table 3. T-Test Result

\begin{tabular}{|c|c|c|c|c|c|}
\hline \multirow[t]{2}{*}{ Model } & \multicolumn{2}{|c|}{$\begin{array}{c}\text { Unstandardized } \\
\text { Coefficients }\end{array}$} & & \multirow[t]{2}{*}{$\mathrm{t}$} & \multirow[t]{2}{*}{ Sig. } \\
\hline & B & Std. Error & $\begin{array}{r}\text { Bet } \\
\mathrm{a}\end{array}$ & & \\
\hline $\begin{array}{ll}1 & \text { (Constan } \\
\text { t) }\end{array}$ & $\begin{array}{r}6.8 \\
45\end{array}$ & 3.251 & & $\begin{array}{r}2.10 \\
6\end{array}$ & .037 \\
\hline $\begin{array}{l}\text { Celebrity } \\
\text { Endorser }\end{array}$ & $\begin{array}{r}.45 \\
1\end{array}$ & .108 & .287 & $\begin{array}{r}4.17 \\
5\end{array}$ & .000 \\
\hline $\begin{array}{l}\text { Brand } \\
\text { Equity }\end{array}$ & $\begin{array}{r}.76 \\
5\end{array}$ & .091 & .580 & $\begin{array}{r}8.43 \\
8\end{array}$ & .000 \\
\hline
\end{tabular}

1. Celebrity Endorser $\left(\mathrm{X}_{1}\right)$ and Purchasing Decision $(\mathrm{Y})$

The table above shows Tcount $>\mathrm{T}_{\text {table }}=4.175>1.655$. Because the amount of $\mathrm{T}_{\text {count }}$ is larger than $\mathrm{T}_{\text {table }}$, then $\mathrm{H}_{0}$ is rejected and $\mathrm{H}_{1}$ is accepted.

2. Brand Equity $\left(\mathrm{X}_{2}\right)$ and Purchasing Decision $(\mathrm{Y})$

The table above shows Tcount $>\mathrm{T}_{\text {table }}=8.438>1.655$. Because the amount of $\mathrm{T}_{\text {count }}$ is larger than $\mathrm{T}_{\text {table }}$, then $\mathrm{H}_{0}$ is rejected and $\mathrm{H}_{1}$ is accepted.

Our research support hypothesis $\left(\mathrm{H}_{1}\right)$, celebrity endorser affects a purchasing decision. This result of research confirms the result of previous studies, Gauns et al. (2017) that found majority of the consumers opined that celebrity endorsement advertisement was more 
attractive than those not endorsed by a celebrity. People were willing to buy a product just because it was endorsed by their favorite celebrity.

Positive results about the purchase intention by the embarrassment of celebrity are also found by Yoon et al. (1998) attractiveness has influenced on purchase intention. Companies believe that celebrities do influence purchase decision of consumers in one or the other way. Hence, Gauns et al. (2017) found that if celebrities are involved in controversy (negative publicity), consumers tend to ignore it and will continue to buy products endorsed by them. Companies must realize that having a celebrity in an advertisement can create a favorable impact on consumers and this, in turn, can influence them to buy the product.

From the result of the second hypothesis $\left(\mathrm{H}_{2}\right)$ testing, it can be found that there is an effect of brand equity on the purchasing decision of a product. It is in line with the result of the previous study (Gunawardane, 2015) finding that increases in brand awareness, brand association, brand loyalty, and perceived quality would generate higher levels of brand equity which is its consequences supported the direct positive impact on purchase intention. Huang et al. (2014) also mentioning that brand equity affects purchase intention. Brand credibility can build brand equityl

In this study brand equity variables proved to have more significant influence. This shows that the brand strength factor still affects customers more in making purchasing decisions, especially for repurchasing. Tighe (2013) stated that to introduce new products in the market, celebrity endorsement is the most appropriate strategy, but to maintain the market, the most appropriate way is to make product brands familiar to customers.

Based on this, in the managerial practice, marketers should prioritize to build product's brand equity as their strategy to attract and retaining their potential customer because the result of this research has proven a significant effect of brand equity to purchase decision.

\section{Limitations And Future Research}

The limitations of this research are firstly related to place (location) because South Sulawesi gives a provincial character to the conclusions reached, and we understand that for this reason, it is not possible to broadly generalize our conclusions. We consider that the present research provides a good approach to the Mabello Product in Sulawesi Market. Future research should include some other regions and markets, in order to generalize. Secondly, we have not addressed other factors affecting the purchase decision in this study, such as the brand attitude, brand preference, price, and other factors affecting the purchase decision. Finally, our study is focused on one unique product. Therefore, for the sake of generalization, further research is needed for different focus product.

\section{Reference}

[1] Aaker, D. A. (1997). Should You Take Your Brand to Where the Action is?. Harvard Business Review, 75 (5): 135-142).

[2] Abdussalam, P. K., \& Johnson, B. (2017). Does Celebrity Endorsement Influence Brand Equity. International Journal of Management Studies, IV(Special Issue-1), 93103.

[3] Akhtar, N., Ulain, Q., Siddiqi, U., Ashraf, A., \& Latif, M. (2016). Impact of a Brand Equity on Consumer Purchase Decision in L'Oreal Skincare Products. International Review of Management and Business Research, Vol 5 (3),1-9 
[4] Chattopadhyay, T., Shivani, S., \& Krishan, M. (2009). Determinants of Brand Equity A Blue print for Building Strong Brands: A Study of The Aultomobile Segment in India. African Journal of Marketing Management, 1(4), 109-121.

[5] Clark, R. C., \& Hortsman, I. J. (2003, 05). is celebrity Advertising Effective Business Standards. Celebrity Endorsents.

[6] Diehl, S, \& Terlutter, Ralf. (2006). International Advertising and Communication: Current Insights and Empirical Findings. Gabler Edition Wissenschaft.

[7] Durianto. (2004). Brand Equity Ten: Strategi Memimpin Pasar. Jakarta: Gramedia.

[8] Elberse, A., and J. Verleun. (2012). The Economic Value of Celebrity Endorsements. Journal of Advertising Research 52 (2), pp 149-165.

[9] Endorgen, B. Z., Baker, M., \& Tagg, S. (2001, May). Selecting Celebrity Endorsers: The Practitioner's Perspective. Journal of Advertising Research, 41(3), 39-48.

[10] Fishbein, M., \& Ajzen , I. (1975). Belief, Attitude, Intention, and Behavior: An Introduction Theory and Research. MA: Addison - Wesley Publishing Company.

[11] Fouladivanda, F., Pashandi, M.A., Hooman, A., Khanmohammadi, Z., 2013. The Effect of Brand Equity on Consumer Buying Behavior in term of FMCG in Iran. Journal of Contemporary Research in Business, 4(9), pp.945-957

[12] Freeman, K. S. (2015). Wither the impact of celebrity endorsement. Paper presented at the International Conference on Communications, Media, Technology and Design, Dubai, UAE. Retrieved from http://www.cmdconf.net/2015/pdf/64.pdf

[13] Gauns, K. K., Bhaskaran P, S. K., Kamat, K., Chen, R. F., \& Chang, L.-C. (2017). Impact of Celebrity Endorsement on Consumer Buying Behaviour in the State of Goa. IIM Kozhikode Society \& Management Review, 7(1), 1-14.

[14] Gunawardane, N. R. (2015, June). Impact of Brand equity towards Purchasing Decision: A situation on Mobile Telecommunication Services of Sri Lanka. Journal of Marketing Management, 3(1), 100-117.

[15] Huang, C. C., Yen, S. W., Liu, C. Y., \& Chang, T. P. (2014). The Relationship among Brand Equity, Customer Satisfaction, and Brand Resonance to Repurchase Intention of Cultural and Creative Industries in Taiwan. International Journal of Organization Innovation, 106-120.

[16] Kanungo R.N \& Pang, S. (1973). Effects of Human Models on Perceived Psychology, 57: $172-178$

[17] Keel, A. (2012). Celebrity Endorsements and Beyond : New Avenues for Celebrity Branding. Psychology and Marketing, 29(9), 690-703

[18] Khan, S. K., Rukhsar, A., \& Shoaib, M. (2016, January). Influence of Celebrity Endorsement on Consumer Purchase Intention. IOSR Journal of Business and Management, 18(1), 06-09.

[19] Knapp, D. E. (2001). The Brand Mindset. New York: McGraw-Hill.

[20] Kotler, P. (2010). Manajemen Pemasaran, Edisi ke 1, Terjemahan Bob Saban. Jakarta.

[21] Kotler, P., \& Armstrong, G. (2008). Priciples of Marketing. Pearson/Prentice Hall.

[22] Kotler, P., \& Keller, K. L. (2009). Marketing Management. New Jersey: Pearson Education Inc.

[23] Kurzman, C, Anderson, C., Key, C., Lee, Y O, Moloney, M., Silver, A., Ryn M W V. (2007). Celebrity Status. Sociological Theory, 25(4)

[24] Martey, E. M., \& Frempong, J. (2014). The Impact Of Celebrities ' Endorsement On Brand Positioning On Mobile Telecommunication Users In The Eastern Region Of Ghana. International Journal of Education Andd Research, 2(7), 397-412. 
[25] Murugananthan, K. M. (2009). Celebrity effect on Brand Positioning: A study with reference to Female Personal Care Products. The International Journal of Applied Management Technology, 7(1), 63-79.

[26] Nayar, P. K. (2009). Seeing Stars Spectacle, Society, and Celebrity Culture. New Delhi: Sage Publication India.

[27] Rangkuti, F. (2002). The Poser of Brands: Teknik Mengelola Brand Equity dan Strategi Pengembangan Merek. Jakarta: Gramedia Pustaka Utama.

[28] Roy, S. (2006). An Exploratory Study in Celebrity Endorsements. Journal of Creative Communications, 1(2), 139-153.

[29] Roy, S. (2012). To Use the Obvious Choice: Investigating the Relative Effectiveness of An Overexposed Celebrity. Journal of Consumer Research, 22, 15-17.

[30] Shazzana, N. (2015). The Influence of Celebrity Endorsement on Actual Purchase Behaviour with Mediating Roe of Brand Equity: A Study on Local Food Brands. University Utara Malaysia: School of Business Management.

[31] Shimp, T. A. (2003). Advertising, Promotion, and Supplemental Aspeccts of Integrated Marketing Communications. Mason, Ohio: Thomson Southwestern. Journal of Marketing Communications, 10 (4). pp.289-290

[32] Sivanandamooorthy, S. (2013). Impact of Celebrity Endorsement on Brand Equity in Cosmetic Product. International Journal of Advanced Research in Management and Social Sciences, 2(4).

[33] Spry, A. (2011). Celebrity Endorsement, Brand Credibility, and Brand Equity. European Journal of Marketing, 45 (6), pp 882-909

[34] Tighe, K. (2013), 3 Ways Startups Can Turn Celebrity Endorsements Into Big Gains. Retrieved from http://www.forbes.com/sites/ theyec/2013/03/08/3-ways-startups-canturn-celebrityendorsementsinto-big-gains/

[35] Yoo, B., Donthu, N., \& Lee, S. (2000). An Examination of Selected Marketing Mix Elements and Brand Equity. Journal of the Academy of Marketing Science, 28(2)

[36] Yoon, K., Kim, C H, \& Kim, M S. (1998). A Cross-Cultural of the Effects of Source Credibility on Attitudes and Behavioral Intentions. Mass Communication \& Society, $1(3 / 4) ; 153-173$ 